\title{
Economic Cost of Injury — United States, 2019
}

\author{
Cora Peterson, $\mathrm{PhD}^{1}$; Gabrielle F. Miller, $\mathrm{PhD}^{1}$; Sarah Beth L. Barnett, $\mathrm{PhD}^{1}$; Curtis Florence, $\mathrm{PhD}^{1}$
}

Unintentional and violence-related injuries, including suicide, homicide, overdoses, motor vehicle crashes, and falls, were among the top 10 causes of death for all age groups in the United States and caused nearly 27 million nonfatal emergency department (ED) visits in 2019.*, CDC estimated the economic cost of injuries that occurred in 2019 by assigning costs for medical care, work loss, value of statistical life, and quality of life losses to injury records from the CDC's Web-based Injury Statistics Query and Reporting System (WISQARS). $\$$ In 2019, the economic cost of injury was $\$ 4.2$ trillion, including $\$ 327$ billion in medical care, $\$ 69$ billion in work loss, and $\$ 3.8$ trillion in value of statistical life and quality of life losses. More than one half of this cost ( $\$ 2.4$ trillion) was among working-aged adults (aged 25-64 years). Individual persons, families, organizations, communities, and policymakers can use targeted proven strategies to prevent injuries and violence. Resources for best practices for preventing injuries and violence are available online from CDC's National Center for Injury Prevention and Control.9

The economic cost estimate for injuries that occurred in 2019 uses the societal perspective, including tangible and intangible costs to multiple payers, and a 1-year time horizon (period over which costs are assessed) for nonfatal injuries. Costs are presented in 2019 U.S. dollars (USD). WISQARS nonfatal injury counts are hospital ED injury visits from the nationally representative National Electronic Injury Surveillance System - All Injury Program. WISQARS fatal injury counts are from CDC's National Vital Statistics System mortality data.

Medical and work loss costs $(1,2)$ were adjusted for patient clinical and demographic characteristics, including

\footnotetext{
* Data on leading causes of death and years of potential life lost are available from https://wisqars.cdc.gov/data/lcd (Accessed November 29, 2021).

${ }^{\dagger}$ Data on estimated number of nonfatal emergency department visits for injuries are available from https://wisqars.cdc.gov/data/non-fatal/explore (Accessed November 29, 2021).

$\$$

https://www.cdc.gov/injury
}

comorbidities, sex, and age, and modified to 2019 USD.** Medical costs were assigned to WISQARS records by injury outcome (fatal or nonfatal), mechanism (e.g., fall), intent (e.g., unintentional), and place of death (e.g., inpatient hospital) or ED visit disposition (treated and released or hospitalized, including transferred). Work loss costs for nonfatal injuries were assigned by injury mechanism and ED visit disposition

\footnotetext{
** U.S. Bureau of Economic Analysis. National Income and Product Accounts: Table 2.5.4: Price Indexes for Personal Consumption Expenditures by Function (37. Health) and Table 1.1.4: Price Indexes for Gross Product D. (1. Gross domestic product); 2020. https://www.bea.gov/itable (Accessed August 3, 2020).
}

\section{INSIDE}

1660 State-Level Economic Costs of Fatal Injuries United States, 2019

1664 Incidence of Nonfatal Traumatic Brain InjuryRelated Hospitalizations — United States, 2018

1669 Vital Signs: HIV Infection, Diagnosis, Treatment, and Prevention Among Gay, Bisexual, and Other Men Who Have Sex with Men - United States, 2010-2019

1676 Notes from the Field: COVID-19 Vaccination Coverage Among Persons Experiencing Homelessness - Six U.S. Jurisdictions, December 2020-August 2021

1679 Correction and Republication: Symptoms of Depression, Anxiety, Post-Traumatic Stress Disorder, and Suicidal Ideation Among State, Tribal, Local, and Territorial Public Health Workers During the COVID-19 Pandemic — United States, MarchApril 2021

1686 QuickStats

Continuing Education examination available at https://www.cdc.gov/mmwr/mmwr_continuingEducation.html

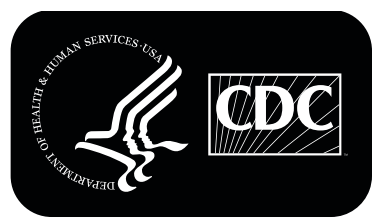


to injured persons of all ages; this approach assumes injured children and older adults incur lost productivity among working-aged adult caregivers. Aggregated medical and work loss costs (e.g., combined intents by mechanism or combined mechanisms by ED visit disposition) from reference sources were assigned when specific estimates by intent or mechanism were not available.

The cost of injury mortality includes value of statistical life, a monetary estimate of the collective value placed on mortality risk reduction as derived in research studies through revealed preferences (e.g., observed wage differences for dangerous occupations) or stated preferences from surveys of individual persons' willingness to pay for mortality risk reduction (3). Value of statistical life estimates were assigned by decedent age: $0-17$ years, $\$ 16.9$ million (4); $18-65$ years, $\$ 10.7$ million (3); and values descending from $\$ 6$ million (aged 66 years) to $\$ 410,000$ (aged $\geq 100$ years), reflecting the estimate for persons aged 18-65 years adjusted for older adults' decreasing general life expectancy and baseline quality of life. Cost of nonfatal injury morbidity includes quality of life losses measured in terms of quality-adjusted life years (QALY; 1 QALY equals 1 year of perfect health) (5) and valued at $\$ 540,000$ per QALY (3). Injury count, rate per 100,000 population, cost by type (medical, work loss, value of statistical life, and quality of life loss), and total cost are reported by intent, sex, and age group. All reported data can be queried online using WISQARS. This activity was reviewed by CDC and was conducted consistent with applicable federal law and CDC policy. ${ }^{\dagger \dagger}$

In 2019 , the economic cost of injury was $\$ 4.2$ trillion, including $\$ 327$ billion in medical care, $\$ 69$ billion in work loss, and $\$ 3.8$ trillion in value of statistical life and quality of life losses (Table). The economic costs were $\$ 2.2$ trillion for fatal injuries and \$2.0 trillion for nonfatal injuries. The number of injury deaths and associated economic cost were higher among males $(169,628$ and $\$ 1.6$ trillion, respectively) than among females (76,413 and $\$ 607$ billion, respectively). The cost of nonfatal injury was similar for males and females (\$1 trillion). Except for nonfatal self-harm, the age-adjusted rate, number, and economic cost for all injury outcomes (fatal and nonfatal) and intents (unintentional, homicide or assault) were higher for males than for females.

Economic cost was highest for persons aged 25-44 and 45-64 years ( $\$ 1.2$ trillion each), followed by those aged $\geq 65$ years ( $\$ 906$ billion), $15-24$ years ( $\$ 512$ billion), and $0-14$ years ( $\$ 396$ billion). Although the injury fatality rate was highest among those aged $\geq 65$ years (132.1 per 100,000 ; mostly unintentional [112.0]), the economic cost of fatal injuries was higher for those aged $25-44$ years ( $\$ 808$ billion) and $45-64$ years ( $\$ 755$ billion) than for those aged $\geq 65$ years

\footnotetext{
$\dagger 45$ C.F.R. part 46, 21 C.F.R. part 56; 42 U.S.C. Sect. 241(d); 5 U.S.C. Sect. 552a; 44 U.S.C. Sect. 3501 et seq.
}

The MMWR series of publications is published by the Center for Surveillance, Epidemiology, and Laboratory Services, Centers for Disease Control and Prevention (CDC), U.S. Department of Health and Human Services, Atlanta, GA 30329-4027.

Suggested citation: [Author names; first three, then et al., if more than six.] [Report title]. MMWR Morb Mortal Wkly Rep 2021;70:[inclusive page numbers].

\section{Centers for Disease Control and Prevention Rochelle P. Walensky, MD, MPH, Director \\ Debra Houry, MD, MPH, Acting Principal Deputy Director \\ Daniel B. Jernigan, MD, MPH, Deputy Director for Public Health Science and Surveillance \\ Rebecca Bunnell, PhD, MEd, Director, Office of Science \\ Jennifer Layden, MD, PhD, Deputy Director, Office of Science \\ Michael F. Iademarco, MD, MPH, Director, Center for Surveillance, Epidemiology, and Laboratory Services}

MMWR Editorial and Production Staff (Weekly)

Charlotte K. Kent, PhD, MPH, Editor in Chief Jacqueline Gindler, MD, Editor

Brian A. King, PhD, MPH, Guest Science Editor

Paul Z. Siegel, MD, MPH, Associate Editor

Mary Dott, MD, MPH, Online Editor

Terisa F. Rutledge, Managing Editor

Teresa M. Hood, MS, Lead Technical Writer-Editor

Leigh Berdon, Glenn Damon, Soumya Dunworth, PhD,

Tiana Garrett-Cherry, PhD, MPH, Srila Sen, MA

Stacy Simon, MA, Morgan Thompson, Technical Writer-Editors

Matthew L. Boulton, MD, MPH

Carolyn Brooks, ScD, MA

Jay C. Butler, MD

Virginia A. Caine, MD

Jonathan E. Fielding, MD, MPH, MBA

David W. Fleming, MD
Martha F. Boyd, Lead Visual Information Specialist

Alexander J. Gottardy, Maureen A. Leahy,

Julia C. Martinroe, Stephen R. Spriggs, Tong Yang, Visual Information Specialists

Quang M. Doan, MBA, Phyllis H. King,

Terraye M. Starr, Moua Yang,

Information Technology Specialists
Ian Branam, MA,

Acting Lead Health Communication Specialist Shelton Bartley, MPH, Leslie Hamlin,

Lowery Johnson, Amanda Ray,

Health Communication Specialists

Will Yang, MA,

Visual Information Specialist

\section{MMWR Editorial Board}

Timothy F. Jones, MD, Chairman

William E. Halperin, MD, DrPH, MPH

Jewel Mullen, MD, MPH, MPA

Jeff Niederdeppe, $\mathrm{PhD}$

Celeste Philip, MD, MPH

Patricia Quinlisk, MD, MPH

Patrick L. Remington, MD, MPH
Carlos Roig, MS, MA

William Schaffner, MD

Nathaniel Smith, MD, MPH

Morgan Bobb Swanson, BS

Abbigail Tumpey, MPH 
TABLE. Number, rates, and estimated costs* of injuries, by outcome, intent, sex, and age group — United States, 2019

\begin{tabular}{|c|c|c|c|c|c|c|c|c|}
\hline \multirow[b]{2}{*}{ Outcome and intent } & \multirow[b]{2}{*}{ Total } & \multicolumn{2}{|c|}{ Sex } & \multicolumn{5}{|c|}{ Age group, yrs } \\
\hline & & Male & Female & $0-14$ & $15-24$ & $25-44$ & $45-64$ & $\geq 65$ \\
\hline Total cost & $4,208,579$ & $2,609,647$ & $1,598,906$ & 396,491 & 512,206 & $1,213,049$ & $1,180,231$ & 905,945 \\
\hline Medical & 326,774 & 179,673 & 147,094 & 33,151 & 38,522 & 82,724 & 77,607 & 94,514 \\
\hline Work loss & 68,729 & 37,085 & 31,642 & 7,472 & 8,751 & 18,165 & 16,758 & 17,545 \\
\hline $\begin{array}{l}\text { Value of statistical life and } \\
\text { quality of life }\end{array}$ & $3,813,077$ & $2,392,888$ & $1,420,170$ & 355,868 & 464,932 & $1,112,160$ & $1,085,866$ & 793,886 \\
\hline \multicolumn{9}{|l|}{ Fatal injuries } \\
\hline \multicolumn{9}{|l|}{ All intents ${ }^{\dagger}$} \\
\hline Rate $^{\S}$ & 71.1 & 102.8 & 40.8 & 9.2 & 54.0 & 86.2 & 84.6 & 132.1 \\
\hline Costs & $2,186,049$ & $1,578,711$ & 607,338 & 94,559 & 267,218 & 808,334 & 754,570 & 261,368 \\
\hline Medical & 3,786 & 2,226 & 1,560 & 88 & 205 & 612 & 723 & 2,158 \\
\hline Value of statistical life & $2,182,263$ & $1,576,484$ & 605,778 & 94,471 & 267,013 & 807,722 & 753,847 & 259,210 \\
\hline \multicolumn{9}{|l|}{ Unintentional } \\
\hline No. of deaths & 173,040 & 112,720 & 60,320 & 3,907 & 11,755 & 48,586 & 48,251 & 60,527 \\
\hline Rate $^{\S}$ & 49.2 & 68.2 & 31.3 & 6.5 & 27.5 & 55.5 & 57.9 & 112.0 \\
\hline Costs & $1,447,643$ & $1,006,091$ & 441,552 & 66,086 & 134,498 & 520,291 & 516,874 & 209,894 \\
\hline Medical & 3,265 & 1,834 & 1,430 & 58 & 114 & 421 & 588 & 2,084 \\
\hline Value of statistical life & $1,444,378$ & $1,004,257$ & 440,122 & 66,028 & 134,384 & 519,870 & 516,286 & 207,810 \\
\hline \multicolumn{9}{|l|}{ Homicide } \\
\hline No. of deaths & 19,141 & 15,264 & 3,877 & 893 & 4,774 & 8,787 & 3,614 & 1,071 \\
\hline Rate $^{\S}$ & 6.0 & 9.6 & 2.4 & 1.5 & 11.2 & 10.0 & 4.3 & 2.0 \\
\hline Costs & 209,019 & 167,502 & 41,517 & 15,109 & 55,581 & 94,105 & 38,710 & 5,514 \\
\hline Medical & 204 & 170 & 34 & 18 & 47 & 84 & 40 & 14 \\
\hline Value of statistical life & 208,816 & 167,332 & 41,484 & 15,092 & 55,533 & 94,021 & 38,670 & 5,500 \\
\hline \multicolumn{9}{|l|}{ Suicide } \\
\hline No. of deaths & 47,511 & 37,256 & 10,255 & 546 & 5,954 & 15,584 & 16,250 & 9,173 \\
\hline Rate $^{\S}$ & 13.9 & 22.4 & 6.0 & 0.9 & 14.0 & 17.8 & 19.5 & 17.0 \\
\hline Costs & 463,193 & 359,092 & 104,102 & 9,235 & 70,567 & 166,836 & 173,946 & 42,610 \\
\hline Medical & 252 & 179 & 73 & 7 & 39 & 87 & 71 & 47 \\
\hline Value of statistical life & 462,941 & 358,912 & 104,029 & 9,227 & 70,528 & 166,749 & 173,875 & 42,562 \\
\hline
\end{tabular}

See table footnotes on the next page.

( $\$ 261$ billion) because of higher value of statistical life cost. The economic cost of suicide deaths was highest among those aged $25-44$ years ( $\$ 167$ billion) and $45-64$ years ( $\$ 174$ billion). The economic cost of deaths from homicide was highest among those aged $25-44$ years ( $\$ 94$ billion), followed by those aged $15-24$ years ( $\$ 56$ billion). The economic cost of nonfatal injuries was highest among those aged $\geq 65$ years ( $\$ 645$ billion), primarily because of quality of life loss costs from unintentional injuries, followed by those aged $45-64$ years ( $\$ 426$ billion), $25-44$ years ( $\$ 405$ billion), 0-14 years ( $\$ 302$ billion), and 15-24 years ( $\$ 245$ billion). The economic cost of nonfatal injuries from assault and self-harm were highest among those aged $25-44$ years ( $\$ 66$ billion and $\$ 10$ billion, respectively).

\section{Discussion}

This report used injury incidence data to estimate the economic cost of injuries that occurred in the United States during 2019. Economic cost was highest among working-aged adults, highlighting that injuries during the most productive part of people's lives result in a high societal cost. These findings highlight the need for targeted prevention strategies to achieve long-term value, or even cost-savings, by preventing injury morbidity and mortality through addressing the causes of unintentional and violence-related injuries at the individual, family, organizational, and community levels.

The 2019 economic cost of injuries ( $\$ 4.2$ trillion) is more than six times as high as a comparable estimate in 2013 (\$671 billion) $(6,7)$. Even though the number of nonfatal ED injury visits in 2019 was approximately 15\% lower than it was in 2013, the 2019 nonfatal injury economic cost (\$2.0 trillion) is more than four times as high as the 2013 estimate ( $\$ 457$ billion) (6), primarily because of including the cost of diminished quality of life. The 2019 fatal injury economic cost ( $\$ 2.2$ trillion) is substantially higher than the similar estimate in 2013 ( $\$ 214$ billion) (7). This difference reflects a $28 \%$ higher number of injury deaths in 2019 and mortality cost based on value of statistical life, which represents a value that is approximately 10 times as high as the value attributed to mortality based on foregone employment compensation, which was used in the previous estimate.

The findings in this report are subject to at least five limitations. First, the economic cost of nonfatal injuries is underestimated because only injuries treated in an ED are included (injuries initially treated in urgent care or doctor's offices not included), 
Morbidity and Mortality Weekly Report

TABLE. (Continued) Number, rates, and estimated costs* of injuries, by outcome, intent, sex, and age group — United States, 2019

\begin{tabular}{|c|c|c|c|c|c|c|c|c|}
\hline \multirow[b]{2}{*}{ Outcome and intent } & \multirow[b]{2}{*}{ Total } & \multicolumn{2}{|c|}{ Sex } & \multicolumn{5}{|c|}{ Age group, yrs } \\
\hline & & Male & Female & $0-14$ & $15-24$ & $25-44$ & $45-64$ & $\geq 65$ \\
\hline \multicolumn{9}{|l|}{ Nonfatal injuries? } \\
\hline \multicolumn{9}{|l|}{ All intents ${ }^{* *}$} \\
\hline No. of injuries & $25,933,780$ & $13,973,305$ & $11,960,119$ & $4,102,128$ & $3,842,368$ & $7,275,609$ & $5,929,789$ & $4,778,380$ \\
\hline Rate $^{\S}$ & $7,881.5$ & $8,699.3$ & $7,037.9$ & $6,772.5$ & $9,001.2$ & $8,305.5$ & $7,116.6$ & $8,839.3$ \\
\hline Costs & $2,022,531$ & $1,030,936$ & 991,568 & 301,932 & 244,988 & 404,716 & 425,661 & 644,577 \\
\hline Medical & 322,988 & 177,447 & 145,534 & 33,063 & 38,317 & 82,112 & 76,884 & 92,356 \\
\hline Work loss & 68,729 & 37,085 & 31,642 & 7,472 & 8,751 & 18,165 & 16,758 & 17,545 \\
\hline Quality of life & $1,630,814$ & 816,404 & 814,392 & 261,397 & 197,919 & 304,438 & 332,019 & 534,676 \\
\hline \multicolumn{9}{|l|}{ Unintentional } \\
\hline No. of injuries & $23,973,103$ & $12,865,348$ & $11,107,407$ & $3,953,061$ & $3,319,180$ & $6,412,723$ & $5,556,825$ & $4,727,632$ \\
\hline Rate $^{\S}$ & $7,256.4$ & $8,001.0$ & $6,484.9$ & $6,526.3$ & $7,775.5$ & $7,320.5$ & $6,669.0$ & $8,745.4$ \\
\hline Costs & $1,840,193$ & 920,286 & 919,881 & 291,077 & 199,765 & 324,816 & 386,194 & 637,937 \\
\hline Medical & 285,673 & 154,120 & 131,548 & 30,854 & 28,092 & 65,722 & 69,641 & 91,250 \\
\hline Work loss & 62,889 & 33,896 & 28,991 & 7,081 & 7,124 & 15,763 & 15,554 & 17,341 \\
\hline Quality of life & $1,491,631$ & 732,271 & 759,342 & 253,143 & 164,549 & 243,330 & 300,999 & 529,345 \\
\hline \multicolumn{9}{|l|}{ Assault } \\
\hline No. of injuries & $1,421,988$ & 854,340 & 567,648 & 101,918 & 348,467 & 659,136 & 277,316 & 33,403 \\
\hline Rate $^{\S}$ & 452.2 & 537.8 & 366.7 & 168.3 & 816.3 & 752.4 & 332.8 & 61.8 \\
\hline Costs & 149,534 & 92,853 & 56,680 & 8,533 & 35,651 & 66,450 & 33,297 & 5,352 \\
\hline Medical & 23,689 & 17,116 & 6,573 & 1,046 & 5,883 & 11,386 & 4,625 & 609 \\
\hline Work loss & 2,605 & 1,821 & 784 & 125 & 605 & 1,229 & 555 & 80 \\
\hline Quality of life & 123,240 & 73,916 & 49,324 & 7,362 & 29,163 & 53,836 & 28,117 & 4,663 \\
\hline \multicolumn{9}{|l|}{ Self-harm } \\
\hline No. of injuries & 460,416 & 186,954 & 273,455 & 46,429 & 157,635 & 158,489 & 82,642 & 15,221 \\
\hline Rate $^{\S}$ & 147.9 & 118.1 & 178.9 & 76.7 & 369.3 & 180.9 & 99.2 & 28.2 \\
\hline Costs & 26,705 & 12,528 & 14,176 & 2,277 & 8,169 & 10,020 & 5,089 & 1,150 \\
\hline Medical & 12,601 & 5,340 & 7,260 & 1,157 & 4,127 & 4,425 & 2,432 & 459 \\
\hline Work loss & 3,104 & 1,259 & 1,845 & 266 & 994 & 1,098 & 627 & 120 \\
\hline Quality of life & 11,000 & 5,929 & 5,071 & 854 & 3,047 & 4,497 & 2,031 & 571 \\
\hline
\end{tabular}

Abbreviation: USD = U.S. dollars.

* In millions of 2019 USD.

${ }^{\dagger}$ Fatal all intents estimates include injuries with legal intervention intent, undetermined intent, unknown sex, and unknown age.

$\S$ Per 100,000. Age-adjusted rate is presented for "Total," "Male," and "Female" columns.

" Nonfatal injuries are an estimated number of hospital visits for injury care that start in an emergency department (with disposition treated and released, transferred, or hospitalized; visits with observed, left against medical advice, and unknown disposition were not included) based on a nationally representative probability sample of hospitals.

** Nonfatal all intents estimates include injuries with legal intervention intent, unknown sex, and unknown age. Nonfatal assault, self-harm, and legal intervention include cases that are confirmed or suspected; all other cases are considered unintentional.

other costs such as property damage and criminal justice are not included, and nonfatal costs address only the first year following an injury. The cost of nonfatal injury includes observed medical care and work loss attributable to injuries based on comparing injured patients and non-injured persons during the year following the injured patient's initial ED visit $(1,2)$. A 1-year time horizon is appropriate for many injury types but does not address the longterm physical and mental health consequences of some injuries (e.g., traumatic brain injury and violence-related injuries). Second, although injury-related medical care and work loss have costs to specific, identifiable payers (including individual persons, health insurance payors, and employers), the highest cost elements presented here are value of statistical life and quality of life losses; these costs are not readily identifiable through financial transactions and thus not as visible to some stakeholders as are direct costs, such as medical care. Third, although this study aimed for a reasonable use of available value of statistical life data, the relationship between value of statistical life and age (particularly, value of statistical life for older adults) is likely more complex than applied here and would benefit from further direct study (8). Fourth, quality of life loss estimates might indirectly capture some work loss; therefore, the nonfatal economic cost estimate might partially double count such costs. Finally, this report provides an initial assessment of the economic cost of injury by intent based on injured person sex and age group. Estimation of injury costs by other demographic and geographic factors within the United States can provide additional meaningful information for injury prevention.

Individual persons, families, organizations, communities, and policymakers can use targeted proven strategies to prevent injuries and violence. Data and resources that can assist in measuring and preventing injuries and violence, including suicide, overdoses, falls, firearm violence, motor vehicle crashes, traumatic brain injury, adverse childhood experiences, youth violence, sexual violence, and intimate partner violence, 


\section{Summary}

What is already known about this topic?

Unintentional and violence-related injuries, including suicide, were among the top 10 causes of U.S. deaths for all age groups and caused nearly 27 million nonfatal emergency department visits in 2019.

What is added by this report?

Fatal and nonfatal injury data from CDC's Web-based Injury Statistics Query and Reporting System were matched to medical care, work loss, value of statistical life, and quality of life loss costs. The estimated U.S. economic cost of injuries in 2019 was $\$ 4.2$ trillion. More than one half of this cost ( $\$ 2.4$ trillion) was among working-aged adults (aged $25-64$ years).

What are the implications for public health practice?

Unintentional and violence-related injuries are costly and preventable. Resources for best practices for preventing injuries and violence are available online from CDC's National Center for Injury Prevention and Control.

are available online from CDC's National Center for Injury Prevention and Control. Opportunities to investigate injury data and costs are available online from WISQARS.

Corresponding author: Cora Peterson, vsm2@cdc.gov, 770-488-0699.

${ }^{1}$ Division of Injury Prevention, National Center for Injury Prevention and Control, CDC.

All authors have completed and submitted the International Committee of Medical Journal Editors form for disclosure of potential conflicts of interest. No potential conflicts of interest were disclosed.

\section{References}

1. Peterson C, Xu L, Barnett SBL. Average lost work productivity due to non-fatal injuries by type in the USA. Inj Prev 2021;27:111-7. PMID:32366517 https://doi.org/10.1136/injuryprev-2019-043607

2. Peterson C, Xu L, Florence C. Average medical cost of fatal and non-fatal injuries by type in the USA. Inj Prev 2021;27:24-33. PMID:31888976 https://doi.org/10.1136/injuryprev-2019-043544

3. Office of the Assistant Secretary for Planning and Evaluation. Guidelines for regulatory impact analysis. Washington, DC: US Department of Health and Human Services, Office of the Assistant Secretary for Planning and Evaluation; 2016. https://aspe.hhs.gov/sites/default/files/migrated_ legacy_files//171981/HHS_RIAGuidance.pdf

4. Office of Child Care, Administration for Children and Families, US Department of Health and Human Services. Child Care and Development Fund (CCDF) program. Final rule. Fed Regist 2016 Sep 30;81(190):67438-595. PMID:27726322

5. Lawrence B, Miller T. Quality of life loss estimation methods for the WISQARS Cost of Injury Module. Calverton, MD: Pacific Institute for Research and Evaluation; 2020. https://www.cdc.gov/injury/wisqars/pdf/ PIRE_WISQARS_cost_injury_quality_life_loss_estimation_ methods-508.pdf

6. Florence C, Haegerich T, Simon T, Zhou C, Luo F. Estimated lifetime medical and work-loss costs of emergency department-treated nonfatal injuries-United States, 2013. MMWR Morb Mortal Wkly Rep 2015;64:1078-82. PMID:26421663 https://doi.org/10.15585/mmwr. mm6438a5

7. Florence C, Simon T, Haegerich T, Luo F, Zhou C. Estimated lifetime medical and work-loss costs of fatal injuries-United States, 2013. MMWR Morb Mortal Wkly Rep 2015;64:1074-7. PMID:26421530 https://doi.org/10.15585/mmwr.mm6438a4

8. Aldy JE, Viscusi WK. Adjusting the value of a statistical life for age and cohort effects. Rev Econ Stat 2008;90:573-81. https://doi.org/10.1162/ rest.90.3.573 